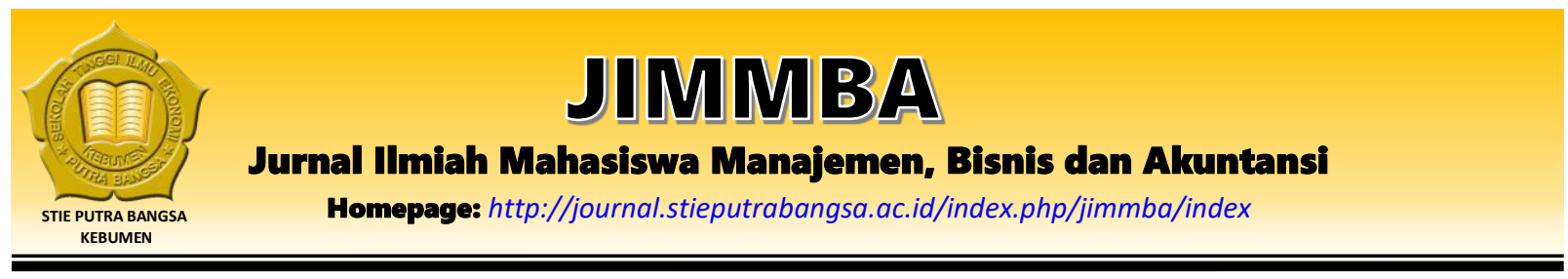

\title{
Pengaruh Service Quality dan Marketing Mix Terhadap Customer Satisfaction Serta Dampaknya Terhadap Repurchase Intention
}

\section{pada Roti Banana}

\author{
Wahid Nur Hidayat ${ }^{1}$, Kabul Trifiyanto ${ }^{2}$ \\ 1,2Sekolah Tinggi Ilmu Ekonomi Putra Bangsa \\ Email: wahidpoenya02@gmail.com¹, kabul.trifiyanto@gmail.com²
}

\section{ARTICLE INFO}

Article History:

Received: November $11^{\text {th }} 2020$ Accepted: November $1^{\text {st }} 2020$

Published: December $31^{\text {st }} 2020$

\section{Keywords:}

Service Quality, Marketing Mix, Customer Satisfaction, Repurchase Intention

\section{ABSTRACT}

Tujuan penelitian ini adalah untuk mengetahui pengaruh service quality dan marketing mix terhadap customer satisfaction dan repurchase intention. Metode pengambilan sampel yang digunakan di penelitian ini adalah nonprobability sampling dengan teknik purposive sampling. Total sampel dalam penelitian ini adalah 100 responden. Metode pengumpulan data menggunakan kuesioner. Analisis data yang digunakan yaitu uji instrument validitas dan reliabilitas, uji asumsi klasik, uji hipotesis dan analisis jalur dengan menggunakan program SPSS 25.0 for windows. Hasil penelitian ini menunjukkan bahwa semua item setiap variabel valid dan reliable. Kedua model struktural memenuhi kriteria uji asumsi klasik dengan tidak tidak terdapat multikolonieritas, heterokedastisitas, dan memenuhi asumsi normalitas. Berdasarkan hasil uji t untuk variabel service quality berpengaruh secara signifikan terhadap customer satisfaction. Variabel marketing mix berpengaruh secara signifikan terhadap customer satisfaction. Variabel service quality berpengaruh secara signifikan terhadap repurchase intention. Variabel marketing mix berpengaruh secara signifikan terhadap repurchase intention. Variabel customer satisfaction berpengaruh secara signifikan terhadap repurchase intention. Besarnya nilai Adjust $\mathrm{R}$ Square adalah 0,353 hal ini berati $35,3 \%$ customer satisfaction dapat dijelaskan oleh service quality dan marketing mix. Nilai Adjust $\mathrm{R}$ Square adalah 0,409 hal ini berarti 40,9\% repurchase intention dapat dijelaskan oleh service quality, marketing mix dan customer satisfaction.

\section{Pendahuluan}

Berkembang pesatnya dunia bisnis dibidang makanan membuat persaingan dagang di Kabupaten Kebumen semakin tinggi. Persaingan dagang yang semakin tinggi, membuat para pengusaha menyusun berbagai strategi bisnis dalam memenangkan persaingan. Berbagai 
strategi bisnis yang dilakukan oleh para pengusaha tidak hanya untuk memenangkan persaingan melainkan untuk keberlangsungan jangka panjang pada bisnisnya. Selain itu, para pengusaha harus mampu

mengelola atau menjalankan manajemen usaha dagangnya serta mampu mengelola konsumen atau pelanggan dengan baik supaya konsumen tidak meninggalkan produk yang sudah lama diminati.

Manajemen usaha dan konsumen merupakan dua unsur yang harus diperhatikan oleh para pengusaha supaya usahanya tetap dapat bersaing. Manajemen usaha dilakukan oleh perusahaan maupun pengusaha dalam menjalankan bisnisnya yang berkaitan dengan manajemen produksi, manajemen pemasaran, manajemen sumber daya manusia serta manajemen keuangan. Sedangkan pengelolaan konsumen merupakan suatu jenis manajemen yang secara khusus membahas teori mengenai penanganan hubungan antara perusahaan dengan konsumen dengan tujuan meningkatkan nilai perusahaan di mata para pelanggannya. Sedangkan menurut Sarinah, (2017: 7) manajemen merupakan suatu proses dalam rangka mencapai tujuan dengan bekerja bersama melalui orang-orang dan sumber daya organisasi lain.

Beberapa perusahaan atau usaha yang terdapat di Kabupaten Kebumen juga melakukan manajemen usaha dan manajemen konsumen. Berdasarkan data yang dilansir oleh tripadvisor pada april 2020 terdapat 10 usaha yang populer di Kabupaten Kebumen dapat dilihat dari tabel 1.

Tabel 1. Daftar TOP 10 Usaha Makanan Terbaik Kabupaten Kebumen

\begin{tabular}{|c|c|c|c|}
\hline No & Nama Usaha & Rating & Reviews \\
\hline 1 & Sate Ambal Pak Kasman & $\overline{4,5}$ & 14 \\
\hline 2 & Candisari Resto Kebumen & 4,0 & 14 \\
\hline 3 & Rumah Makan Bu Nanang & 4,0 & 12 \\
\hline 4 & Banana Bread and Cakes Kebumen & 4,5 & 7 \\
\hline 5 & Waroeng Djoglo Resto & 4,0 & 5 \\
\hline 6 & Warung Bakso M. Tohir Putra & 4,5 & 2 \\
\hline 7 & Rumah Makan Yunani 19 & 3,5 & 6 \\
\hline 8 & Tengleng dan Kambing Bakar Al Bar & 5,0 & 1 \\
\hline 9 & Qiye Resto dan Cafe Bu Diro & 5,0 & 1 \\
\hline 10 & Mang Engking Putra Gombong & 5,0 & 1 \\
\hline
\end{tabular}

Berdasarkan data diatas terdapat 10 macam usaha yang berkembang dengan baik di wilayah Kabupaten Kebumen. Penilaian usaha tersebut dilihat dari nilai rating dengan indikator penilaian food, service dan value, serta jumlah reviews dengan indikator traveler rating, traveler type dan language. Namun dari semua usaha tersebut memiliki jenis produk usaha yang berbeda-beda. Salah satu jenis usaha yang terdapat dalam TOP 10 usaha adalah usaha bakery atau bergerak dibidang pembuatan dan penjualan roti. Oleh karena itu, penulis melakukan observasi terhadap 65 responden yang menjadi konsumen usaha bakery di Kabupaten Kebumen. 
Tabel 2. Observasi Konsumen atau Pelanggan Bakery di Kabupaten Kebumen

\begin{tabular}{lll}
\hline Toko Roti Kebumen & Jumlah Konsumen & Prosentase \\
\hline Banana & 53 & $81.5 \%$ \\
Gucci & 6 & $9.2 \%$ \\
Purimas & 5 & $7.7 \%$ \\
Yuna & 1 & $1.5 \%$ \\
Bati & 0 & $0.0 \%$ \\
Jempol & 0 & $0.0 \%$ \\
Laziza & 0 & $0.0 \%$ \\
Jumlah & $\mathbf{6 5}$ & $\mathbf{1 0 0} \%$ \\
\hline
\end{tabular}

Sumber: Data Primer diolah 2020.

Berdasarkan hasil observasi yang telah dilakukan kepada 65 responden yang pernah melakukan pembelian produk roti di Kebumen, hasil menunjukan bahwa produk roti Banana masih menjadi produk unggulan. Hasil observasi menunjukan bahwa dari 65 responden, 53 $(81,5 \%)$ orang memilih dan membeli produk Banana, $6(9,2 \%)$ orang dari 65 responden memilih dan membeli produk Gucci, 5 (7,7\%) orang dari 65 memilih dan membeli produk Purimas, dan $1(1,5 \%)$ orang dari 65 memilih dan membeli produk Yuna. Hasil observasi tersebut dapat diartikan bahwa Banana Bread and Cakes Kebumen atau Roti Banana masih menjadi produk favorit dan paling pupuler yang banyak dibeli oleh masyarakat di Kabupaten Kebumen.

Banana Bread and Cakes Kebumen merupakan salah satu usaha bakery milik keluarga yang berdiri sejak tajun 1990 di Kabupaten Kebumen dengan beberapa cabang usaha di wilayah luar kota. Awal mula berdirinya usaha ini bergerak dibidang restoran, namun seiring perkembangan usaha ini beralih ke produksi roti hingga berkembang pesat dan dikenal masyarakat Kebumen dengan merk yang kuat. Usaha ini memiliki visi untuk melakukan inovasi menciptakan produk yang berkelanjutan dengan mengedepankan kepuasan pelanggan yang terdapat di daerah Kabupaten Kebumen.

Produk dari Banana Bread and Cakes Kebumen memiliki akar barat tetapi sangat dipengaruhi oleh teknik, tekstur, dan selera Asia. Usaha ini selalu berinovasi dan berkembang untuk melampaui harapan pelanggan dan menjadi inspirasi bagi orang lain. Usaha ini mengadopsi merek "Pisang" bukan karena terinspirasi oleh pisang sebagai buah tropis, tetapi dipengaruhi oleh produk asli usaha ini yang mengandung banyak rasa pisang. Produk-produk ini sangat populer di kalangan pelanggan setia. Oleh karena popularitasnya dan pengucapannya yang umum dalam berbagai bahasa, pemilik memutuskan untuk mengadopsi merek "Banana".

Observasi lanjutan telah dilakukan untuk mengetahui daya tarik apa yang membuat masyarakat di Kabupaten Kebumen memilih produk dari Usaha Banana Bread and Cakes Kebumen atau Roti Banana. Hasil observasi terhadap 65 responden tersebut dapat dilihat pada tabel 3 yang menyajikan data terhadap pelanggan setia Roti Banana Kebumen.

Tabel 3. Data Responden Pelanggan Roti Banana Kabupaten Kebumen

\begin{tabular}{llll}
\hline No & Variabel & Jumlah Pelanggan & Persentase \\
\hline 1 & Service Quality & 13 & $20 \%$ \\
2 & Marketing Mix & & \\
& a. Product (produk) & 25 & $38,5 \%$ \\
& b. Price (harga) & 19 & $29,2 \%$ \\
& c. Place (tempat) & 5 & $7,7 \%$ \\
& d. Promotion & 3 & $4,6 \%$ \\
\multirow{2}{*}{ Jumlah } & $\quad$ (promosi) & $\mathbf{6 5}$ & $\mathbf{1 0 0} \%$ \\
\hline
\end{tabular}

Sumber: Data Primer diolah 2020. 
Berdasarkan data pada tabel 3 menyatakan bahwa pelanggan memberikan respon pada service quality sebanyak 13 orang atau $20 \%$ menyatakan kepuasannya. Selanjutnya untuk marketing mix yang terdiri dari product, price, place dan promotion adalah 25 responden atau 38,5\% memilih product, 19 responden atau 29,2\% memilih price, 5 responden atau 7,7\% memilih place dan 3 responden atau $4,6 \%$ memilih promotion. Hasil observasi tersebut dapat diartikan bahwa $20 \%$ responden puas terhadap service quality dan $80 \%$ responden puas terhadap marketing mix pada Usaha Banana Bread and Cakes Kebumen. Data telah menunjukan bahwa usaha Banana Bread and Cakes Kebumen menggunakan service quality.

Service Quality menurut Kotler and Armstrong (2004:283) menyatakan sebagai kualitas produk yang memiliki hubungan erat dengan kemampuan produk untuk menjalankan fungsinya, termasuk keseluruhan produk, keandalan, ketepatan, kemudahan pengoperasian dan perbaikan, dan atribut bernilai lainnya. Jadi kualitas produk merupakan sekumpulan ciri dan karakteristik dari barang dan jasa yang mempunyai kemampuan untuk memenuhi kebutuhan para konsumen, yang merupakan suatu pengertian gabungan dari keandalan, ketapatan, kemudahan, pemeliharaan serta atribut-atribut lainnya dari suatu produk.

Menurut persepsi pelanggan terhadap kualitas interaksi adalah Ressponsivness, Assurance dan Empathy, mengacu pada kesediaan penyedia layanan untuk membantu pengguna dan memberikan layanan yang cepat (Akter et al 2010;. DeLone dan McLean 2003;. Parasuraman et al 1988). Service quality merupakan suatu kondisi dinamis yang berpengaruh dengan produk, jasa, manusia, proses dan lingkungan yang memenuhi atau melebihi harapan (Tjiptono, 2001). Jika jasa yang diterima atau dirasakan baik dan memuaskan, jika jasa yang diterima melampaui harapan konsumen, maka kualitas pelayanan dipersepsikan sangat baik dan berkualitas. Sebaliknya jika jasa yang diterima lebih rendah daripada yang diharapkan, maka kualitas pelayanan dipersepsikan buruk (Tugiso dan Haryono, 2016; 8).

Sedangkan menurut Oliver (1993), kualitas pelayanan dibentuk oleh perbandingan antara ideal dengan persepsi dari kinerja dimensi kualitas. Pengukuran kualitas pelayanan oleh Parasuraman et.al., (1985) pada riset eksplanatorinya, menjelaskan pelayanan dan faktor-faktor yang menentukannya. Dalam penelitian ini didefinisikan bahwa kualitas pelayanan sebagai derajat ketidakcocokan antara harapan normative pelanggan pada jasa dan persepsi pelanggan pada kinerja pelayanan yang diterima. Untuk menghindari agar tidak terjadi perbedaan persepsi tentang apa yang diberikan oleh perusahaan dengan apa yang dibutuhkan oleh konsumen itu sendiri memerlukan manajemen untuk mengidentifikasikan apa yang dibutuhkan oleh konsumen secara tepat. Kualitas dimulai dari kebutuhan konsumen dan berakhir pada persepsi konsumen (Kotler, 1997). Hal ini dapat diartikan bahwa kualitas yang baik dilihat dari persepsi konsumen bukan dari persepsi perusahaan. Persepsi konsumen terhadap kualitas pelayanan merupakan penilaian total atas keunggulan suatu produk yang dapat berupa barang ataupun jasa.

Keberhasilan pemasaran suatu produk sering tidak cukup hanya dengan menawarkan berbagai keunggulan yang dimiliki oleh jasa tersebut. Adapula penggunaan stratergi marketing mix (bauran pemasaran) yang harus dilakukan oleh perusahaan untuk keberlangsungan usahanya dan memenangkan persaingan pasar. Marketing mix (bauran pemasaran) merupakan suatu strategi penjualan atau promosi serta penentuan harga yang bersifat unik serta dirancang untuk menghasilkan pertukaran yang saling menguntungkan untuk pasar yang dituju.

Menurut Azizah (2010), keberhasilan atau kegagalan suatu perusahan dalam menjual produkproduknya di pasar dapat diketahui dari perkembangan penjualan yang dinyatakan dalam barang yang terjual. Oleh karena itu para pengusaha mengunakan strategi-strategi jitu untuk menarik minat kosumen, strategi yang digunakan strategi bauran pemasaran (marketing mix). Menurut Ratih Hurriyati (2010:28) menyatakan bahwa bauran pemasaran merupakan unsur- 
unsur pemasaran yang saling terkait, dibaurkan, diorganisir, dan digunakan dengan tepat, sehingga perusahaan dapat mencapai tujuan pemasaran dengan efektif, sekaligus memuaskan kebutuhan dan keinginan konsumen.

Marketing mix (bauran pemasaran) terdiri dari produk (Product), harga (Price), sistem distribusi (Place), dan kegiatan promosi (Promotion). Bauran pemasaran adalah suatu wujud rencana yang terurai di bidang pemasaran, di mana untuk memperoleh hasil yang optimal di dalam penelitian mengenai pemasaran. Bauran pemasaran merupakan suatu strategi yang umumnya dilakukan oleh perusahaan untuk melakukan analisa mengenai strategi pemasaran suatu produk. Hal ini dikarenakan bauran pemasaran memiliki ruang lingkup yang luas akan strategi pemasaran.

Dalam kondisi persaingan yang ketat, hal utama yang harus diprioritaskan adalah kepuasan pelanggan (customer satisfaction) yang pada akhirnya akan menarik minat pelanggan untuk membeli ulang suatu produk sehingga perusahaan dapat bertahan, bersaing dan menguasai pangsa pasar. Customer satisfaction juga merupakan bagian penting dalam mempertahankan pelanggan. Menurut Cohen et al (2006) dalam Hardjanti dan Amalia (2014) customer satisfaction merupakan kunci utama dalam mempertahankan pelanggan. Menurut Kotler dan Keller (2009) customer satisfaction adalah perasaan senang atau kecewa sesorang yang timbul karena membandingkan kinerja yang dipersepsikan produk (atau hasil) terhadap ekspektasi mereka. Banyak penelitian yang meneliti pengaruh kepuasan terhadap customer retention, dan hasilnya memang berpengaruh secara signifikan. Semakin tingginya customer satisfaction juga akan memperbaiki atau menambahkan kualitas customer retention. Kepuasan konsumen Roti Banana terhadap program-program loyalitas terhadap pelanggan serta service quality yang memuaskan, tentu saja akan meningkatkan repurchase intention (pembelian ulang) pada konsumen Roti Banana.

Thamrin (2003), menyatakan bahwa minat beli ulang suatu produk dipengaruhi langsung oleh kepuasan pelanggan pada merek yang diakumulasikan melalui waktu. Anderson et al (1994) menyatakan bahwa apabila pelanggan puas terhadap produk atau layanan yang diberikan, akan menimbulkan kesetiaan pelanggan sehingga membuat pelanggan melakukan pembelian ulang (repurchase) di masa yang akan datang, menurunkan elastisitas harga, menghambat pesaing menarik pelanggan karena pelanggan enggan berpindah (switching), menurunkan biaya dan waktu transaksi berikutnya, menurunkan biaya penanganan ketidaksesuaian produk/jasa, menurunkan biaya pencarian pelanggan baru karena pelanggan akan cenderung menginformasikan kepada calon pelanggan lainnya, karena perusahaan memiliki produk dan layanan yang memuaskan, sehingga reputasi perusahaan turut terangkat.

Adanya kepuasan pelanggan (customer satisfaction) yang membuat para pelanggan malakukan pembelian ulang (repurchase intention) pada produk yang sudah diminatinya. Repurchase Intention (pembelian ulang) merupakan intensi untuk melakukan pembelian kembali akan suatu produk sebanyak dua kali atau lebih, baik terhadap produk yang sama maupun yang berbeda (Zeng, Zuahao, Rong, \& Zhilin, 2009). Repurchase ini meliputi 2 karakteristik yaitu intention (intensi) dan behavior (perilaku). Repurchase intention ini erat kaitannya dengan sikap konsumen terhadap objek dan sikap konsumen terhadap perilaku sebelumnya. Penelitan Akhter (2010) menemukan bahwa kepuasan tidak secara langsung berhubungan dengan repurchase (pembelian kembali), namun tidak salah bahwa kepuasan konsumen berpengaruh pada perilaku pembelian kembali jika dilihat dari riset psikologi dimana kepuasan mendorong intensi dan intensi mendorong perilaku. Oleh karena itu tidak dapat dipungkiri repurchase adalah salah satu indikator dari kepuasan dan juga efek dari pembelian. 


\section{Kajian Teori dan Telaah Literatur}

\section{Repurchase Intention}

Salah satu dampak membeli produk adalah repurchase atau pembelian kembali. Repurchase Intention adalah intensi untuk melakukan pembelian kembali akan suatu produk sebanyak dua kali atau lebih, baik terhadap produk yang sama maupun yang berbeda (Zeng, Zuahao, Rong, \& Zhilin, 2009). Repurchase ini meliputi 2 karakteristik yaitu intention (intensi) dan behavior (perilaku). Repurchase intention ini erat kaitannya dengan sikap konsumen terhadap objek dan sikap konsumen terhadap perilaku sebelumnya. Menurut Ike Kusdyah (2012) minat beli ulang merupakan salah satu dari perilaku pembelian konsumen dimana terdapat keseuaian antara nilai dari barang atau jasa yang dapat menghasilkan minat konsumen untuk mengkonsumsinya lagi di kemudian hari. Keinginan konsumen untuk melakukan pembelian ulang suatu barang, sebagian besar didasarkan pada rasa percaya dan value yang berkaitan dengan penggunaan barang tersebut. Hal tersebut didukung oleh pernyataan Anoraga dalam Ike Kusdyah (2012) bahwa minat beli ulang adalah minat konsumen dalam membeli yang dilihat dari pengalaman pembelian yang telah dilakukan pada masa yang lalu. Menurut Putri (2016), Minat beli ulang (repurchase intention) adalah kecenderungan sikap pembelian konsumen terhadap produk yang dilakukan berulang-ulang dalam jangka waktu tertentu ysng didasarkan pada pengalaman di masa lalu.

Thamrin, (2003) menyatakan bahwa minat beli ulang suatu produk dipengaruhi langsung oleh kepuasan pelanggan pada merek yang diakumulasikan melalui waktu. Anderson et al (1994), menyatakan bahwa apabila pelanggan puas terhadap produk atau layanan yang diberikan, akan menimbulkan kesetiaan pelanggan sehingga membuat pelanggan melakukan pembelian ulang (repurchase) di masa yang akan datang, menurunkan elastisitas harga, menghambat pesaing menarik pelanggan karena pelanggan enggan berpindah (switching), menurunkan biaya dan waktu transaksi berikutnya, menurunkan biaya penanganan ketidaksesuaian produk/jasa, menurunkan biaya pencarian pelanggan baru karena pelanggan akan cenderung menginformasikan kepada calon pelanggan lainnya, karena perusahaan memiliki produk dan layanan yang memuaskan, sehingga reputasi perusahaan turut terangkat.

Teori Tindakan Beralasan (Theory of Reasoned Action) yang dikembangkan oleh Icek Ajzen dan Martin Fishbein pada tahun 1980 (dalam Jogiyanto, 2007) mengasumsikan bahwa konsumen secara sadar mempertimbangkan segala informasi pada alternatif-alternatif yang ada dan akhirnya akan memilih satu alternatif yang dapat memberikan konsekuensi yang paling diharapkan. Hawkins \& Mothersbaugh (2010) menambahkan konsumen bisa terus melakukan pembelian kembali walaupun tidak punya keterikatan emosional terhadap suatu produk atau barang. Hawkins \& Mothersbaugh (2001), juga mengungkapkan bahwa konsumen yang tidak puas pada pembelian sebelumnya dapat melakukan pembelian kembali atau repurchase dengan beberapa faktor seperti tidak ada barang pengganti, kesusahan melakukan exit, belum ada barang pengganti dan berbagai kemudahan lain yang disediakan. 


\section{Customer Satisfaction}

Kepuasan pelanggan (customer satisfaction) ditentukan oleh persepsi pelanggan atas performance (kinerja) produk atau jasa dalam memenuhi harapan pelanggan (Irawan, 2010). Pelanggan akan merasa puas apabila harapannya terpenuhi atau akan sangat puas jika harapannya terlampaui. Harapan yang dimaksud di sini adalah persepsi pelanggan sebelum dan sesudah menggunakan suatu produk. Persepsi didefinisikan sebagai proses di mana individu memilih, mengorganisasikan, serta mengartikan stimulus yang diterima alat inderanya menjadi suatu makna (Rangkuti, 2006). Meskipun demikian, makna dari proses persepsi tersebut juga dipengaruhi oleh pengalaman masa lalu individu itu sendiri. Proses persepsi terhadap suatu jasa tidak mengharuskan pelanggan menggunakan jasa tersebut terlebih dulu.

Pada dasarnya, customer atau konsumen merupakan aset yang sangat berharga dan harus dijaga dalam dunia bisnis. Konsumen juga mempunyai harapan mengenai perasaan yang ingin mereka rasakan ketika mereka menyelesaikan suatu transaksi atau ketika mereka menggunakan barang yang mereka beli maupun saat menikmati pelayanan yang telah mereka bayar. Sangat penting bagi para pelaku bisnis untuk dapat memenuhi kebutuhan dan harapan-harapan pelanggannya (Annisa Indah Puspita et al: 2018). Sebuah perusahaan dapat menghasilkan kepuasaan pelanggan dengan cara memenuhi kebutuhan dan harapan pelanggan lebih dari apa yang dibayangkan pelanggan.

Menurut Kotler dan Keller (2009) kepuasan pelanggan adalah perasaan senang atau kecewa seseorang yang timbul karena membandingkan kinerja yang dipersepsikan produk (atau hasil) terhadap ekspektasi mereka. Menurut Nasution (2001:45) dalam Andika dan Brillyanes (2017: 2) customer satisfaction adalah suatu keadaan yang meliputi kebutuhan, keinginan, dan harapan pelanggan yang dapat terpenuhi melalui produk yang dikonsumsi atau jasa yang digunakan.

\section{Marketing Mix}

Menurut William J. Stanston (2006: 30), marketing mix is the term that is used to described the combination of the four inputs that constitute the core of an organization's marketing system. These four elements are the product offering, the price structure, the promotion activities, and the distribution system. Definisi tersebut berarti bahwa bauran pemasaran adalah istilah yang digunakan untuk menggambarkan kombinasi dari empat input yang merupakan inti dari sistem pemasaran organisasi. Keempat elemen tersebut adalah penawaran produk, struktur harga, kegiatan promosi dan sistem distribusi.

Menurut Buchari Alma (2011: 205), marketing mix merupakan strategi mencampurkan kegiatan-kegiatan marketing, agar dicari kombinasi maksimal sehingga mendatangkan hasil paling memuaskan. Sedangkan menurut Kotler dan Amstrong (2012: 75), marketing mix is the set of tactical marketing tools that the firm blends to produce the response it want in the target market. Definisi tersebut berarti bahwa bauran pemasaran merupakan seperangkat alat pemasaran yang digunakan perusahaan untuk terus menerus mencapai tujuan perusahaannya dalam pasar sasaran.

Kotler \& Armstrong (2012: 25) menyatakan bauran pemasaran (marketing mix) merupakan alat pemasaran yang digunakan oleh perusahaan untuk medapatkan respon dari target pasar. 
Marketing mix terdiri dari beberapa alat pemasaran yang terdiri dari $4 \mathrm{P}$ yaitu product, price, place, dan promotion.

\section{Service Quality}

Menurut Kotler dan Keller (2009: 169), Service Quality adalah "Quality is the totality of features and characteristics of a product or service that bear on its ability to satisfy stated or implied needs" yang berarti bahwa kualitas adalah keseluruhan dari fitur dan karakteristik dari sebuah produk atau jasa yang memiliki kemampuan untuk memuaskan kebutuhan. Sedangkan Zeithaml (2006), mengemukakan bahwa kualitas layanan atau service quality merupakan elemen kritis dari persepsi pelanggan akan produk jasa yang diterimanya. Khususnya dalam suatu produk yang murni jasa, service quality akan menjadi elemen yang dominan dalam penilaian pelanggan.

Pada umumnya sebuah jasa diproduksi dan dikonsumsi secara bersamaan. Evaluasi konsumen terhadap sebuah pelayanan tentu berbeda dengan melakukan evaluasi terhadap produk karena adanya beberapa perbedaan karakteristik antara keduanya. Hal tersebut membuat jasa lebih sulit untuk dievaluasi karena penilaiannnya didasarkan pada pelayanan yang dialami oleh konsumen.

Dalam mencapai dan menghasilkan suatu kualitas jasa yang baik, suatu perusahaan jasa haruslah mengerti dan mengimplementasikan segala dimensi-dimensi kualitas jasa dengan tepat, karena para pelanggan dalam menilai kualitas jasa suatu perusahaan, mereka menggunakan persepsinya dengan melihat dan merasakan dimensi-dimensi kualitas jasa yang ditawarkan suatu perusahaan.

\section{Model Penelitian}

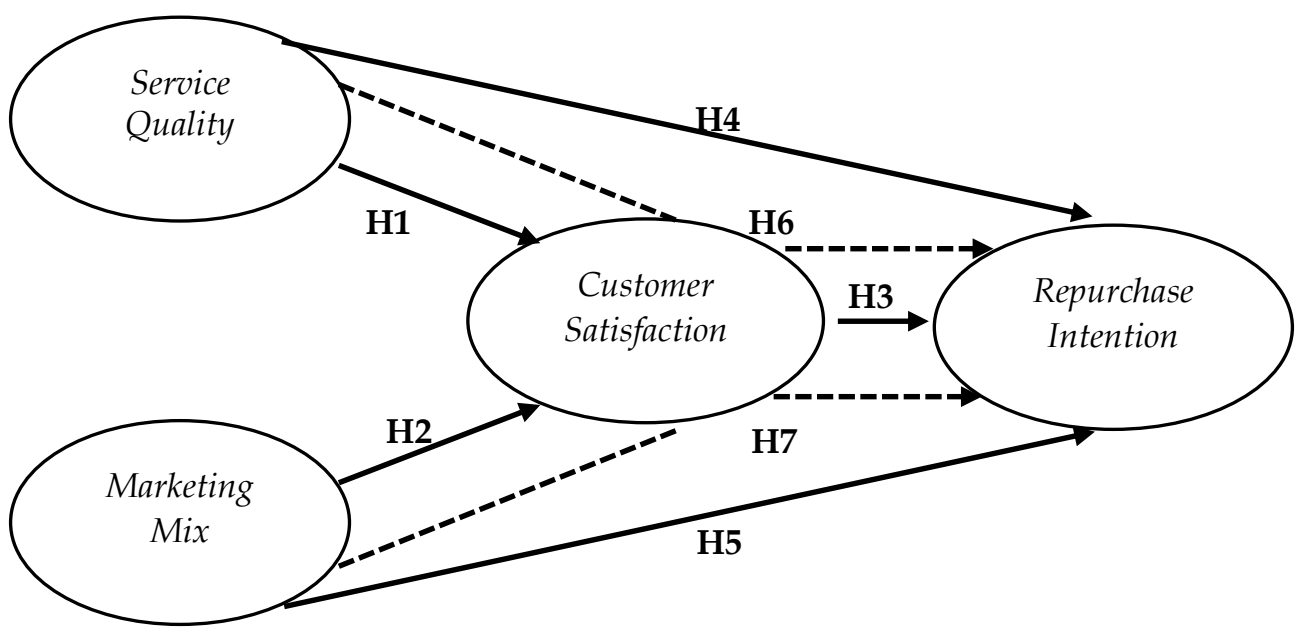

Gambar 1. Model Penelitian

\section{Hipotesis}

Berdasarkan uraian tersebut, hipotesis dalam penelitian ini adalah:

H1 : Service Quality berpengarih positif terhadap Customer Satisfaction

H2 : Marketing Mix berpengaruh positif terhadap Customer Satisfaction

H3 : Customer Satisfaction berpengaruh positif terhadap Repurchase Intention

H4 : Service Quality berpengaruh positif terhadap Repurchase Intention 
H5 : Marketing Mix berpengaruh positif terhadap Repurchase Intention

H6 : Service Quality berpengaruh terhadap Repurchase Intention dengan Customer Satisfaction sebagai variabel intervening

H7 : Marketing Mix berpengaruh terhadap Repurchase Intention dengan Customer Satisfaction sebagai variabel intervening

\section{Metode Penelitian}

\section{Subyek dan Obyek Penelitian}

Subyek dalam penelitian ini adalah konsumen atau pelanggan toko Roti Banana (Banana Bread and Cakes) di Kebumen yang melakukan pembelian minimal 2 kali dalam 3 Bulan terakhir atau secara rutin. Sedangkan objek dalam penelitian ini adalah variabel service quality dan marketing mix sebagai variabel bebas (independen), sedangkan variabel repurchase intention sebagai variabel terikat (dependen) serta variabel customer satisfaction sebagai variabel intervening.

\section{Populasi dan Sampel Penelitian}

Menurut Sugiyono (2018: 136) populasi adalah wilayah generalisasi yang terdiri atas objek/subjek yang mempunyai kualitas dan karakterisitik tertentu yang ditetapkan oleh peneliti untuk dipelajari dan kemudian ditarik kesimpulannya. Populasi dalam penelitian ini yaitu masyarakat di Kabupaten Kebumen yang pernah melakukan pembelian Roti Banana di Banana Bread and Cakes Kebumen. Menurut Sugiyono (2018: 137), sampel adalah bagian dari jumlah dan karakteristik yang dimiliki oleh populasi tersebut. Sampel yang diambil dari populasi harus benar-benar data representatif (mewakili) daripada populasi. Pemilihan sampel yang akan digunakan dalam penelitian ini adalah dengan menggunakan metode nonprobability sampling, yaitu teknik pengambilan sampel yang tidak memberikan peluang/kesempatan sama bagi setiap unsur atau anggota populasi untuk dipilih menjadi sampel kembali. Dalam nonprobability sampling akan digunakan teknik purposive sampling dimana teknik tersebut merupakan pemilihan anggota sampel dengan mempertimbangkan syarat-syarat yang telah ditetapkan sebelumnya. Syarat sampel dalam penelitian ini adalah masyarakat Kebumen yang melakukan pembelian Roti Banana minimal 2 kali dalam 3 Bulan terakhir pada Banana Bread and Cakes Kebumen.

\section{Analisis Statistik Deskriptif}

Analisis deskriptif adalah transformasi data mentah ke dalam bentuk yang mudah dipahami atau diinterpretasi. Analisis deskriptif, yang juga disebut analisis pendahuluan, bertujuan untuk mengetahui karakteristik setiap variabel dalam sampel. Analisis deskriptif diperoleh dari jawaban kuesioner seperti jumlah responden, usia, alamat dan lain-lain. Hasil analisis ini juga dapat dipakai sebagai bahan pertimbangan untuk menentukan analisis dalam uji hipotesis (Simamora, 2004: 231).

\section{Analisis Statistik}

Analisis statistik atau kuantitatif digunakan untuk menganalisis data dari hasil jawaban kuisioner dengan menggunakan metode-metode statistik. Analisis data kuantitatif ini menggunakan kuesioner sebagai alat bantu analisis yang berasal dari sampel sebanyak 100 responden yang melakukan pembelian Roti Banana minimal 2 kali dalam satu tahun terakhir pada Banana Bread and Cakes Kebumen. Teknik analisis data dalam penelitian ini menggunakan alat bantu berupa program aplikasi komputer yaitu SPSS (Statistica Product and Service Solutions) 25.0 for windows. 
Hasil dan Pembahasan

Analisis Deskriptif

Karakteristik Responden Berdasarkan Jenis Kelamin

Tabel 4. Jenis Kelamin Responden

\begin{tabular}{llll}
\hline No & Jenis Kelamin & Jumlah & Persentase \\
\hline 1. & Laki-laki & 25 & $25 \%$ \\
2. & Perempuan & 75 & $75 \%$ \\
\hline \multicolumn{7}{l}{ Jumlah } & $\mathbf{1 0 0}$ & $\mathbf{1 0 0} \%$ \\
\multicolumn{3}{l}{ Sumber: Data Primer } & diolah, 2020 \\
\hline
\end{tabular}

Berdasarkan tabel 4, menunjukan bahwa 25 responden berjenis kelamin laki-laki dengan persentase sebanyak $25 \%$, sedangkan 75 responden berjenis kelamin perempuan dengan persentase sebanyak $75 \%$.

\section{Karakteristik Responden Berdasarkan Usia}

Tabel 5. Usia Responden

\begin{tabular}{cccc}
\hline No & Usia & Jumlah & Persentase \\
\hline 1. & $17-25$ & 90 & $90 \%$ \\
2. & $26-35$ & 7 & $7 \%$ \\
3. & $36-45$ & 2 & $2 \%$ \\
4. & Diatas $>45$ & 1 & $1 \%$ \\
\hline \multicolumn{2}{c}{ Jumlah } & $\mathbf{1 0 0}$ & $\mathbf{1 0 0 \%}$ \\
\hline
\end{tabular}

Sumber: Data primer diolah, 2020

Berdasarkan tabel 5, menunjukan bahwa karakteristik responden dengan usia terbanyak yaitu pada usia 17-25 tahun sebanyak 90 responden atau 90\%. Usia 26-35 tahun sebanyak 7 responden atau 7\%, usia 36-45 tahun sebanyak 2 responden atau 2\% dan usia $>45$ tahun sebanyak 1 responden atau 1\%. Dengan demikian diketahui bahwa masyarakat Kabupaten Kebumen dengan usia 17-25 tahun merupakan jumlah terbanyak yang pernah melakukan pembelian produk Banana Bread and Cake Kebumen.

\section{Karakteristik Responden Berdasarkan Pekerjaan}

Tabel 6. Pekerjaan Responden

\begin{tabular}{ccc}
\hline Pekerjaan & Frekuensi & Prosentase \\
\hline Karyawan Swasta & 75 & $75 \%$ \\
Pelajar/Mahasiswi & 10 & $10 \%$ \\
Wiraswasta & 8 & $8 \%$ \\
PNI/TNI/POLRI & 6 & $6 \%$ \\
Lainnya & 1 & $1 \%$ \\
\hline Jumlah & $\mathbf{1 0 0}$ & $\mathbf{1 0 0} \%$ \\
\hline
\end{tabular}

Sumber: Data primer diolah, 2020

Berdasarkan tabel 6, menunjukkan bahwa responden terbanyak adalah karyawan swasta yaitu sebanyak 75 responden atau $75 \%$, pelajar/mahasiswa sebanyak 10 responden atau $10 \%$, wiraswasta sebanyak 8 responden atau 8\%, PNS/TNI/Polri sebanyak 6 responden $6 \%$, dan lainnya sebanyak 1 responden atau 1\%. Dengan demikian diketahui bahwa pekerjaan 
responden atau masyarakat Kecamatan Kebumen terbanyak yang telah melakukan pembelian produk Banana Bread and Cake Kebumen adalah karyawan swasta.

\section{Uji Validitas dan Reliabilitas}

\section{Uji Validitas Service Quality (X1)}

Tabel 7. Hasil Uji Validitas Service Quality

\begin{tabular}{lllll}
\hline Variabel & Butir & $\mathbf{r}_{\text {hitung }}$ & $\mathbf{r}_{\text {tabel }}$ & Ket \\
\hline \multirow{3}{*}{ Service } & 1 & 0,744 & 0,197 & Valid \\
Quality & 2 & 0,619 & 0,197 & Valid \\
& 3 & 0,636 & 0,197 & Valid \\
& 4 & 0,749 & 0,197 & Valid \\
& 5 & 0,646 & 0,197 & Valid \\
\hline
\end{tabular}

Sumber: Data diolah menggunakan SPSS versi 25.0, 2020

Uji Validitas Marketing Mix (X2)

Tabel 8. Hasil Uji Validitas Marketing Mix

\begin{tabular}{lllll}
\hline Variabel & Butir & $\mathbf{r}_{\text {hitung }}$ & $\mathbf{r}_{\text {tabel }}$ & Ket \\
\hline & 1 & 0,487 & 0,197 & Valid \\
& 2 & 0,636 & 0,197 & Valid \\
& 3 & 0,568 & 0,197 & Valid \\
Marketing Mix & 4 & 0,679 & 0,197 & Valid \\
& 5 & 0,565 & 0,197 & Valid \\
& 6 & 0,635 & 0,197 & Valid \\
& 7 & 0,607 & 0,197 & Valid \\
& 8 & 0,662 & 0,197 & Valid \\
\hline
\end{tabular}

Sumber: Data diolah menggunakan SPSS versi 25.0, 2020

Uji Validitas Customer Satisfaction (Y1)

Tabel 9. Hasil Uji Validitas Customer Satisfaction

\begin{tabular}{ccccc}
\hline Variabel & Butir & $\mathbf{r}_{\text {hitung }}$ & $\mathbf{r}_{\text {tabel }}$ & Ket \\
\hline \multirow{2}{*}{ Customer } & 1 & 0,597 & 0,197 & Valid \\
Satisfaction & 2 & 0,740 & 0,197 & Valid \\
& 3 & 0,769 & 0,197 & Valid
\end{tabular}

Sumber: Data diolah menggunakan SPSS versi 25.0, 2020

Uji Validitas Repurchase Intention (Y2)

Tabel 10. Hasil Uji Validitas Repurchase Intention

\begin{tabular}{lllll}
\hline Variabel & Butir & $\mathbf{r}_{\text {hitung }}$ & $\mathbf{r}_{\text {tabel }}$ & Ket \\
\hline \multirow{2}{*}{ Repurchase } & 1 & 0,785 & 0,197 & Valid \\
Intention & 2 & 0,770 & 0,197 & Valid \\
& 3 & 0,673 & 0,197 & Valid \\
\hline
\end{tabular}


Sumber: Data diolah menggunakan SPSS versi 25.0, 2020

Berdasarkan tabel 8,9,10 dan 11 tersebut, dapat diketahui bahwa nilai $\mathrm{r}_{\text {hitung }}$ dari masingmasing butir pernyataan yang terdapat dalam kuisioner yang telah disebarkan lebih besar dari nilai $r_{\text {tabel }}(0,197)$ dengan nilai signifikansi kurang dari 0,050 , sehingga seluruh item pernyataan yang digunakan pada seluruh variabel dapat dinyatakan valid.

\section{Uji Reliabilitas}

Tabel 11. Hasil Uji Reliabilitas

\begin{tabular}{lllll}
\hline No & Variabel & CA & Syarat & Status \\
\hline 1 & Service Quality & 0,708 & $\mathrm{a}>0,60$ & Reliabel \\
2 & Marketing Mix & 0,748 & $\mathrm{a}>0,60$ & Reliabel \\
3 & Customer Satisfaction & 0,777 & $\mathrm{a}>0,60$ & Reliabel \\
4 & Repurchase Intention & 0,796 & $\mathrm{a}>0,60$ & Reliabel \\
\hline \multicolumn{4}{l}{ Sumber: Data diolah menggunakan SPSS versi $25.0,2020$}
\end{tabular}

Berdasarkan tabel 12, dapat dijelaskan bahwa seluruh variabel yang digunakan dalam penelitian ini dinyatakan reliabel karena nilai Cronbach's Alpha yang dimiliki oleh masingmasing variabel lebih dari 0,60 .

\section{Uji Asumsi Klasik}

\section{Uji Multikolinieritas}

Tabel 12. Uji Multikolinieritas Substruktural 1

\begin{tabular}{ccc}
\hline \multirow{2}{*}{ Variabel } & \multicolumn{2}{c}{ Collinearity Statistics } \\
\cline { 2 - 3 } & Tolerance & VIF \\
\hline Service Quality & 0.631 & 1.584 \\
Marketing Mix & 0.631 & 1.584 \\
\hline Sumber: Data diolah menggunakan SPSS versi 25.0, 2020
\end{tabular}

Tabel 13. Uji Multikolinieritas Substruktural 2

\begin{tabular}{ccc}
\hline \multirow{2}{*}{ Variabel } & \multicolumn{2}{c}{ Collinearity Statistics } \\
\cline { 2 - 3 } & Tolerance & VIF \\
\hline Service Quality & 0.563 & 1.776 \\
Marketing Mix & 0.571 & 1.752 \\
Customer Satisfaction & 0.634 & 1.578 \\
\hline Sumber: Data diolah menggunakan SPSS versi 25.0, 2020
\end{tabular}

Berdasarkan tabel 12 dan 13 diatas, menunjukan bahwa collinearity statistic pada nilai tolerance lebih besar dari 0,10 dan VIF tidak lebih besar dari 10, sehingga dapat diambil kesimpulan bahwa model regresi struktural 1 dan 2 ini tidak terjadi multikolinieritas sehingga model dapat dipakai. 


\section{Uji Heteroskedastisitas}

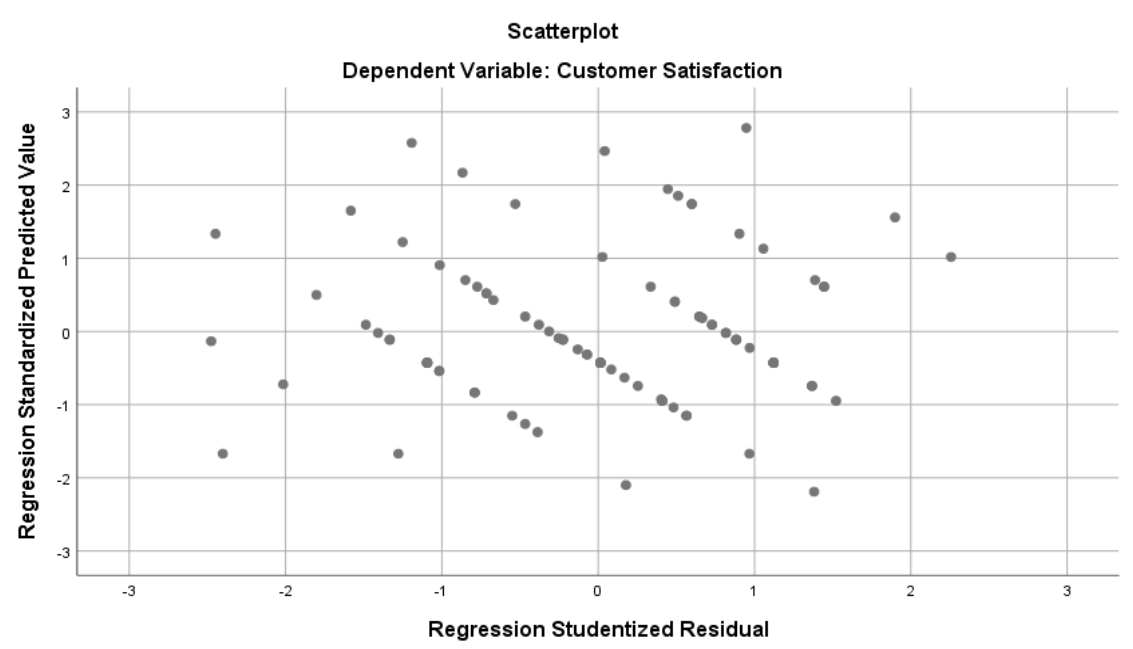

Gambar 2. Uji Heteroskedastisitas Substruktural 1

Sumber: Data diolah menggunakan SPSS versi 25.0, 2020

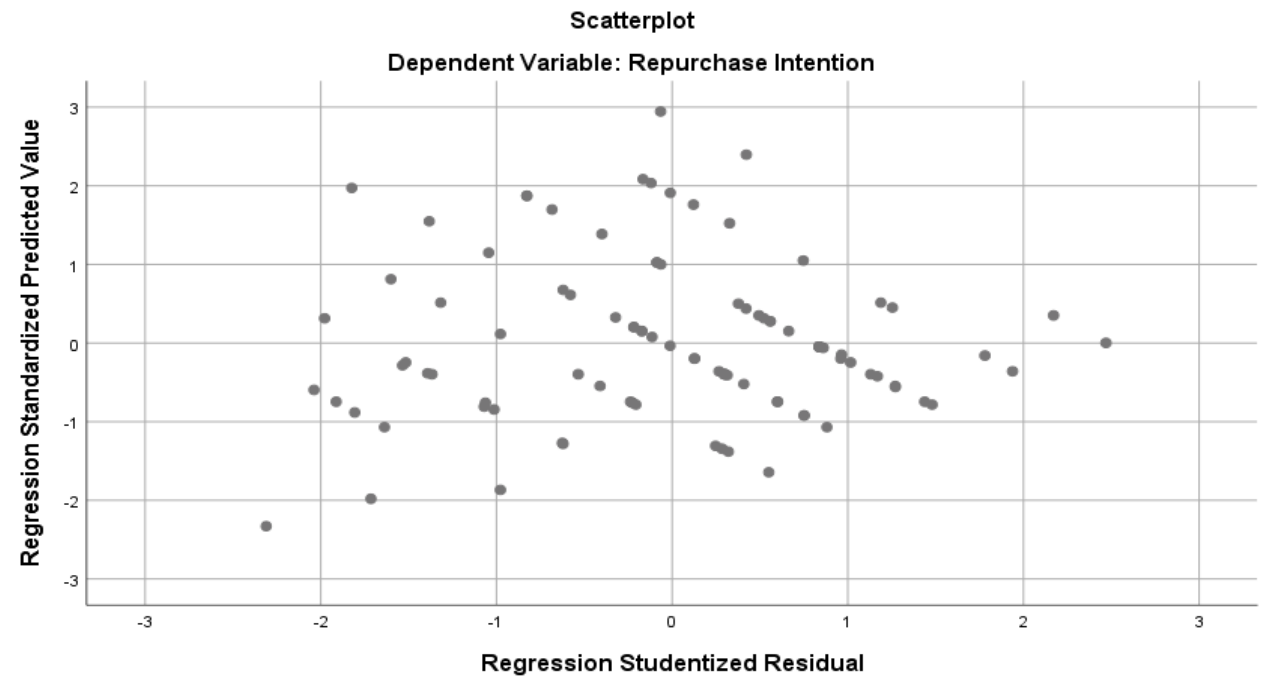

Gambar 3. Uji Heteroskedastisitas Substruktural 2

Sumber: Data diolah menggunakan SPSS versi 25.0, 2020

Berdasarkan gambar 2 dan 3, menunjukan bahwa tidak ada pola tertentu seperti titik-titik yang membentuk pola tertentu (bergelombang, melebar, kemudian menyempit) dan tidak ada pola yang jelas sehingga dapat disimpulkan model regresi persamaan 1 dan 2 dalam penelitian ini tidak terjadi heteroskedastisitas. 


\section{Uji Normalitas}

\section{Grafik Normalitas P-Plot}

Normal P-P Plot of Regression Standardized Residual

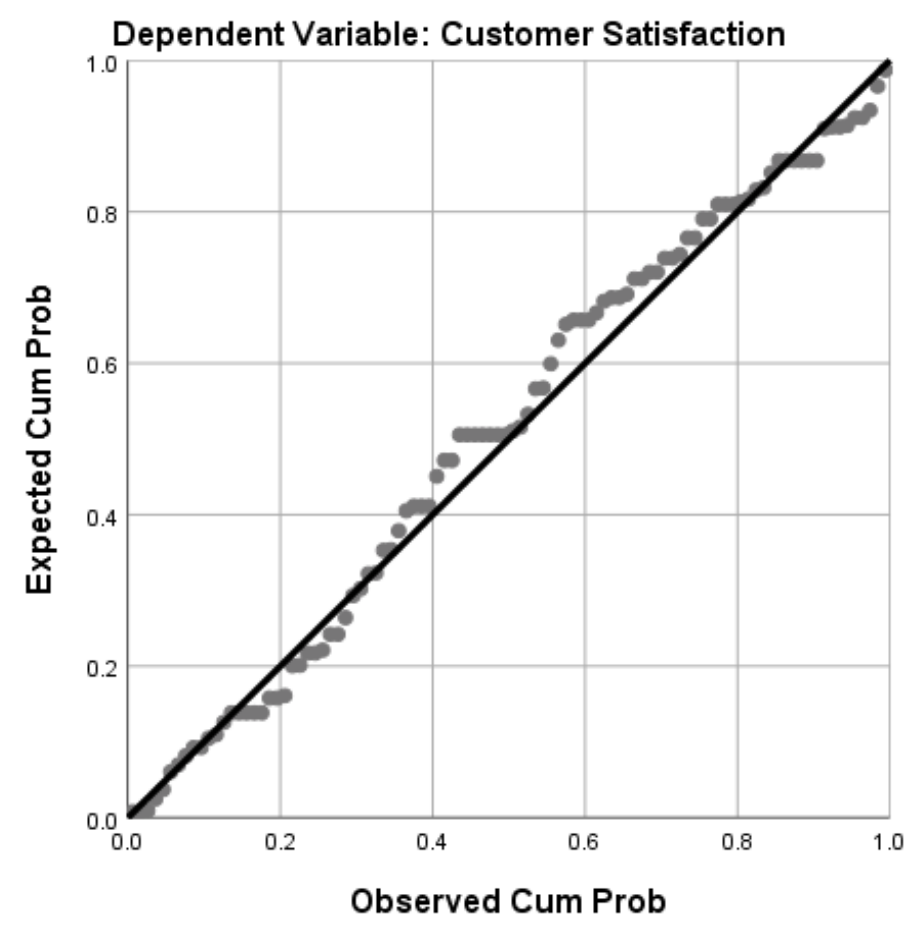

Gambar 4. Uji Normalitas Substruktural 1

Sumber: Data diolah menggunakan SPSS versi 25.0, 2020

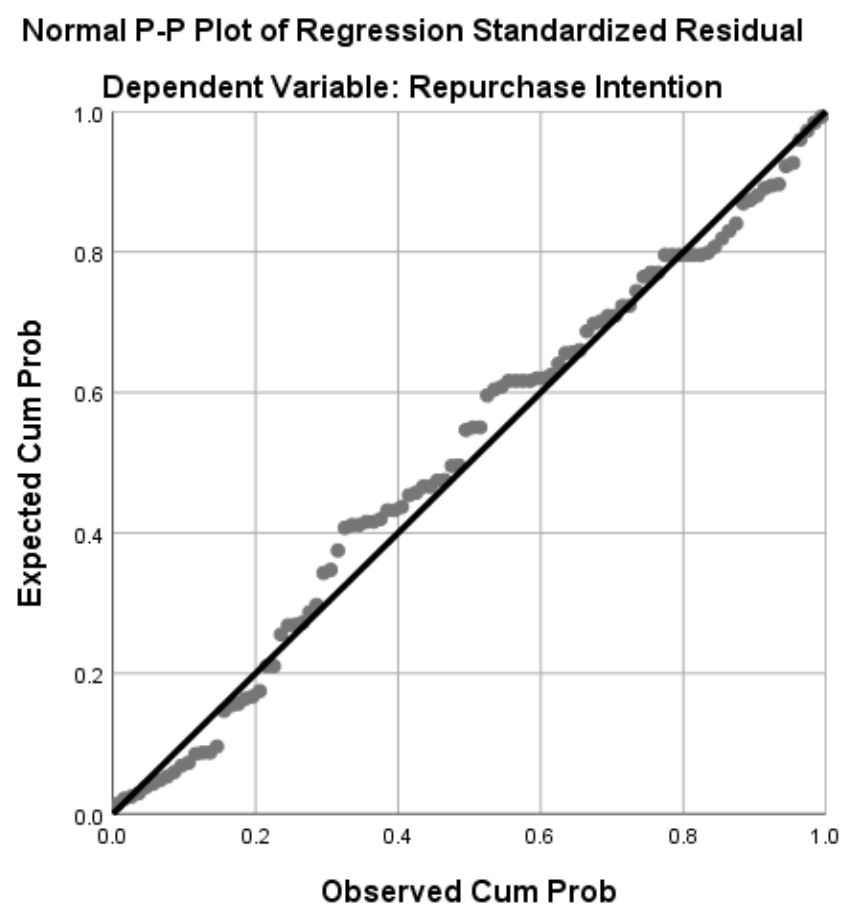

Gambar 5. Uji Normalitas Substruktural 2

Sumber: Data diolah menggunakan SPSS versi 25.0, 2020 
Berdasarkan gambar 4 dan 5 tersebut, dapat diketahui bahwa data menyebar di sekitar garis diagonal dan mengkuti arah garis diagonal. Dengan demikian model regresi persamaan 1 dan 2 memenuhi asumsi normalitas.

Uji Kolmogorov-Smirnov

Tabel 14. Kolmogorov-Smirnov Substruktural 1

One-Sample Kolmogorov-Smirnov Test

\begin{tabular}{lll} 
& & \multicolumn{1}{l}{ Standardized Residual } \\
\hline $\mathrm{N}$ & & 100 \\
\hline Normal & Mean & .0000000 \\
\cline { 2 - 3 } Parametersa & Std. Deviation & .98984745 \\
\hline Most Extreme & Absolute & .083 \\
\cline { 2 - 3 } Differences & Positive & .051 \\
\cline { 2 - 3 } & Negative & -.083 \\
\hline Test Statistic & & .083 \\
\hline Asymp. Sig. (2-tailed) & $.088^{\mathrm{c}}$ \\
\hline
\end{tabular}

Sumber: Data diolah menggunakan SPSS versi 25.0, 2020

Tabel 15.Kolmogorov-Smirnov Substruktural 2

One-Sample Kolmogorov-Smirnov Test

\begin{tabular}{|c|c|c|}
\hline \multirow{2}{*}{\multicolumn{2}{|c|}{$\overline{\mathrm{N}}$}} & \multirow{2}{*}{$\begin{array}{l}\text { Standardized Residual } \\
100\end{array}$} \\
\hline & & \\
\hline Normal & Mean & .0000000 \\
\hline Parameters ${ }^{\mathrm{a}, \mathrm{b}}$ & Std. Deviation & .98473193 \\
\hline Most Extreme & Absolute & .086 \\
\hline \multirow[t]{2}{*}{ Differences } & Positive & .057 \\
\hline & Negative & -.086 \\
\hline Test Statistic & & .086 \\
\hline Asymp. Sig. (2 & tailed) & $.066^{c}$ \\
\hline
\end{tabular}

Sumber: Data diolah menggunakan SPSS versi 25.0, 2020

Berdasarkan tabel 14 dan 15 yang merupakan hasil output dari olah data SPSS 25.0 tersebut, diketahui bahwa nilai signifikansi Asymp. Sig. (2-tailed) sebesar 0,088 dan 0,066 >0,05. Sesuai dengan hasil tersebut dapat disimpulkan bahwa data berdistribusi normal.

\section{Uji Hipotesis}

\section{Uji Parsial (Uji t)}

Tabel 16. Uji Parsial (Uji t) Substruktural 1

\begin{tabular}{|c|c|c|c|}
\hline \multicolumn{4}{|c|}{ Coefficients $^{a}$} \\
\hline & Model & $\mathrm{t}$ & Sig. \\
\hline \multirow[t]{3}{*}{1} & (Constant) & 2.602 & .011 \\
\hline & Service Quality & 3.431 & .001 \\
\hline & Marketing Mix & 3.203 & .002 \\
\hline
\end{tabular}

a. Dependent Variable: Customer Satisfaction

Sumber: Data diolah menggunakan SPSS versi 25.0, 2020 
Tabel 17. Uji Parsial (Uji t) Substruktural 2

\begin{tabular}{cccc}
\multicolumn{4}{c}{ Coefficients $^{\mathbf{a}}$} \\
\hline \multirow{4}{*}{1} & Model & $\mathrm{t}$ & Sig. \\
& (Constant) & -2.198 & .197 \\
& Service Quality & 2.312 & .023 \\
& Marketing Mix & 2.737 & .007 \\
& Customer Satisfaction & 2.655 & .009 \\
\hline
\end{tabular}

a. Dependent Variable: Repurchase Intention

Sumber: Data diolah menggunakan SPSS versi 25.0, 2020.

Hasil uji $t$ untuk variabel service quality (X1) menunjukan bahwa nilai $t_{\text {hitung }}$ sebesar $3,431>t_{\text {tabel }}$ 1,985 dengan tingkat signifikan sebesar 0,001 <0,05 maka $\mathrm{H}_{0}$ ditolak $\mathrm{H}_{1}$ diterima.

Hasil uji t untuk variabel marketing mix (X2) menunjukan bahwa nilai $t_{\text {hitung }}$ sebesar 3,203 $>t_{\text {tabel }}$ 1,985 dengan tingkat signifikan sebesar 0,002 < 0,05 maka $\mathrm{H}_{0}$ ditolak $\mathrm{H}_{1}$ diterima.

Hasil uji $t$ untuk variabel service quality (X1) menunjukan bahwa nilai $t_{\text {hitung }}$ sebesar $2,312>t_{\text {tabel }}$ 1,985 dengan tingkat signifikan sebesar $0,023<0,05$ maka $\mathrm{H}_{0}$ ditolak $\mathrm{H}_{1}$ diterima.

Hasil uji t untuk variabel marketing mix (X2) menunjukan bahwa nilai $t_{\text {hitung }}$ sebesar $2,737>t_{\text {tabel }}$ 1,985 dengan tingkat signifikan sebesar 0,007 < 0,05 maka $\mathrm{H}_{0}$ ditolak $\mathrm{H}_{1}$ diterima.

Hasil uji t untuk variabel customer satisfaction (Y1) menunjukan bahwa nilai $t_{\text {hitung }}$ sebesar 2,655 $<t_{\text {tabel }} 1,985$ dengan tingkat signifikan sebesar 0,009 > 0,05 maka $\mathrm{H}_{0}$ diterima $\mathrm{H}_{1}$ ditolak.

\section{Uji Koefisien Determinasi $\left(\mathbf{R}^{2}\right)$}

Tabel 18. Koefisien Determinasi 1 Model Summary

\begin{tabular}{|c|c|c|c|c|}
\hline \multicolumn{5}{|c|}{ Model Summaryb } \\
\hline Model & $\mathrm{R}$ & R Square & $\begin{array}{l}\text { Adjusted R } \\
\text { Square }\end{array}$ & Durbin-Watson \\
\hline 1 & $.605^{\mathrm{a}}$ & .366 & .353 & 1.950 \\
\hline
\end{tabular}

Sumber: Data diolah menggunakan SPSS versi 25.0, 2020

Berdasarkan tabel 18 tersebut besarnya Adjust $R$ Square adalah 0,353 hal ini berati 35,3\% customer satisfaction dapat dijelaskan oleh service quality dan marketing mix. Sedangkan sisanya $(100 \%-35,3 \%)=64,7 \%$ dijelaskan oleh faktor lain diluar model.

Tabel 19. Koefisien Determinasi 2 Model Summary ${ }^{b}$

\begin{tabular}{ccccc}
\hline Model & R & R Square & $\begin{array}{c}\text { Adjusted R } \\
\text { Square }\end{array}$ & Durbin-Watson \\
\hline 1 & $.653^{\text {a }}$ & .427 & .409 & 2.098
\end{tabular}

a. Predictors: (Constant), Customer Satisfaction, Marketing Mix, Service Quality

b. Dependent Variable: Repurchase Intention

Sumber: Data diolah menggunakan SPSS versi 25.0, 2020 
Berdasarkan tabel 19 tersebut besarnya Adjust $R$ Square adalah 0,409 hal ini berarti 40,9\% repurchase intention dapat dijelaskan oleh service quality, marketing mix dan customer satisfaction. Sedangkan sisanya $(100 \%-40,9 \%)=59,1 \%$ dijelaskan oleh faktor lain diluar model.

\section{Analisis Korelasi}

Tabel 20. Hasil Analisis Korelasi

\begin{tabular}{|c|c|c|c|}
\hline \multicolumn{4}{|l|}{ Correlations } \\
\hline & & Service Quality & Marketing Mix \\
\hline \multirow[t]{4}{*}{ Service Quality } & Pearson & 1 & $.607^{* *}$ \\
\hline & Correlation & & \\
\hline & Sig. (2-tailed) & & .000 \\
\hline & $\mathrm{N}$ & 100 & 100 \\
\hline \multirow[t]{4}{*}{ Marketing Mix } & Pearson & $.607^{* *}$ & 1 \\
\hline & Correlation & & \\
\hline & Sig. (2-tailed) & .000 & \\
\hline & $\mathrm{N}$ & 100 & 100 \\
\hline
\end{tabular}

**. Correlation is significant at the 0.01 level (2-tailed). Sumber: Data diolah menggunakan SPSS versi 25.0, 2020

Berdasarkan tabel 20, dapat dijelaskan bahwa service quality dan marketing mix memiliki angka koefisien korelasi sebesar 0,607 dimana hal ini dapat diartikan bahwa terdapat hubungan korelasi kuat diantara kedua variabel tersebut.

\section{Uji Sobel}

Pengaruh service quality terhadap repurchase intention melalui customer satisfaction

Tabel 21. Uji Sobel

\begin{tabular}{lll}
\hline Test Statistic & Standar Error & P-Vallue \\
\hline 2.10129036 & 0.03690304 & 0.03561549 \\
\hline
\end{tabular}

Sumber: Data diolah menggunakan SPSS versi 25.0, 2020

Pengaruh marketing mix terhadap repurchase intention melalui customer satisfaction

Tabel 22. Uji Sobel

\begin{tabular}{lll}
\hline Test Statistic & Standar Error & P-Vallue \\
\hline 2.0565005 & 0.02429869 & 0.04000957
\end{tabular}

Sumber: Data diolah menggunakan SPSS versi 25.0, 2020

Berdasarkan tabel 22 dan 23 menunjukan bahwa test statistic $>t_{\text {tabel }}$ dan $p$-value $<a$. Maka dapat disimpulkan bahwa customer satisfaction dapat memediasi antara variabel service quality dan marketing mix dengan repurchase intention. 


\section{Analisis Jalur (Path Analysis)}

Pengaruh Langsung (Direct Effect atau DE)

Untuk mengetahui pengaruh langsung atau DE digunakan formula sebagai berikut:

1. Pengaruh variabel Service Quality terhadap Customer Satisfaction $\mathrm{X} 1 \rightarrow \mathrm{Y} 1=0,349$

2. Pengaruh variabel Marketing Mix terhadap Customer Satisfaction $\mathrm{X} 2 \rightarrow \mathrm{Y} 1=0,326$

3. Pengaruh variabel Customer Satisfaction terhadap Repurchase Intention $\mathrm{X} 1 \rightarrow \mathrm{Y} 2=0,258$

4. Pengaruh variabel Service Quality terhadap Repurchase Intention $\mathrm{X} 2 \rightarrow \mathrm{Y} 2=0,238$

5. Pengaruh variabel Marketing Mix terhadap Repurchase Intention $\mathrm{Y} 1 \rightarrow \mathrm{Y} 2=0,280$

Pengaruh Tidak Langsung (Indirect Effect atau IE)

Untuk menghitung pengaruh tidak langsung atau IE digunakan formula sebagai berikut:

1.Pengaruh variabel Service Quality terhadap Repurchase Intention melalui Customer Satisfaction

$\mathrm{X} 1 \rightarrow \mathrm{Y} 1 \rightarrow \mathrm{Y} 2=\left(0,349^{*} 0,258\right)=0,090$

2. Pengaruh variabel Marketing Mix terhadap Repurchase Intention melalui Customer Satisfaction

$\mathrm{X} 2 \rightarrow \mathrm{Y} 1 \rightarrow \mathrm{Y} 2=(0,326 * 0,258)=0,084$

Pengaruh Total (Total Effect)

Untuk mengetahui pengaruh total digunakan formula sebagai berikut:

1.Pengaruh variabel Service Quality terhadap Repurchase Intention melalui Customer Satisfaction

$\mathrm{X} 1 \rightarrow \mathrm{Y} 1 \rightarrow \mathrm{Y} 2=(0,349+0,258)=0,607$

2. Pengaruh variabel Marketing Mix terhadap Repurchase Intention melalui Customer Satisfaction

$\mathrm{X} 2 \rightarrow \mathrm{Y} 1 \rightarrow \mathrm{Y} 2=(0,326+0,258)=0,584$ 


\section{Diagram Jalur}

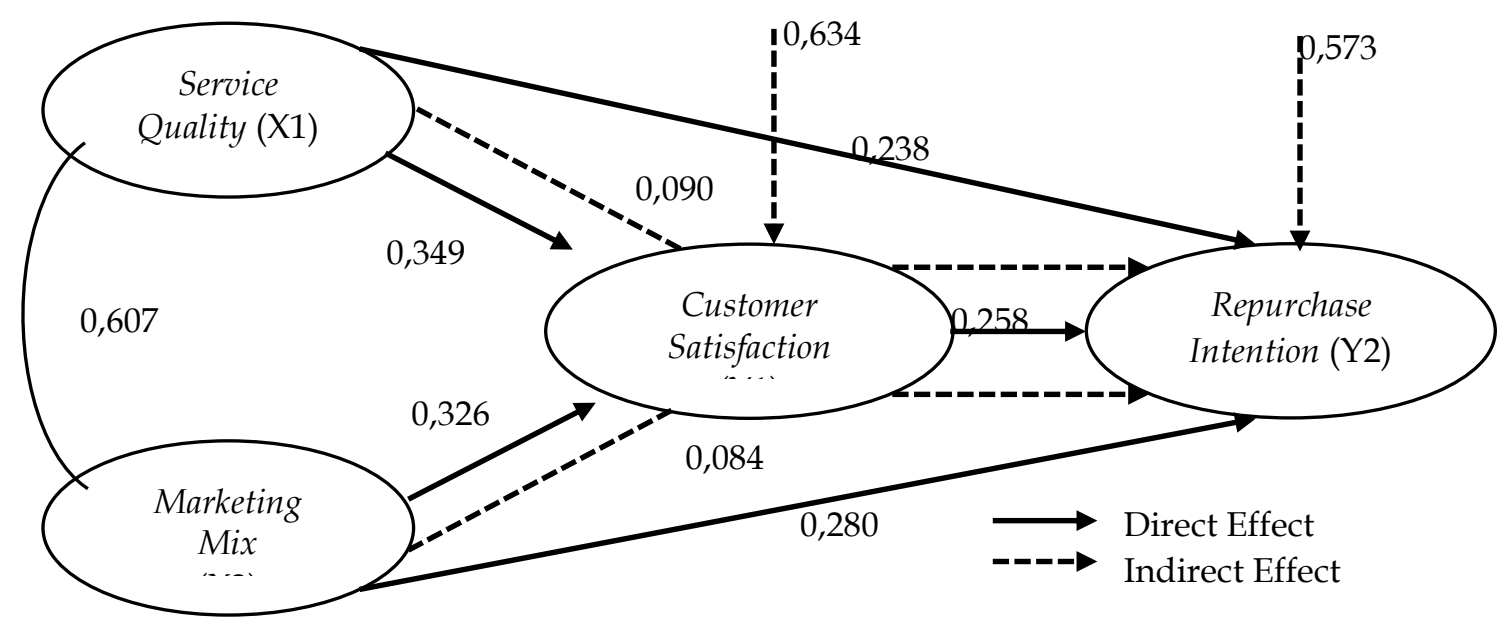

Gambar 6. Diagram Jalur

\section{Pembahasan}

\section{Pengaruh service quality terhadap customer satisfaction}

Pengujian hipotesis pertama dilakukan untuk mengetahui pengaruh service quality terhadap customer satisfaction. Berdasarkan hasil uji t untuk variabel service quality diperoleh nilai $t_{\text {hitung }}$ lebih besar dari $t_{\text {tabel }}$ yaitu $3.431>1.985$ dengan nilai signifikansi sebesar $0.001<0.05$. Hal ini menunjukan bahwa variabel service quality berpengaruh signifikan terhadap variabel customer satisfaction. Hasil tersebut berarti bahwa semakin baik kualitas pelayanan (service quality) pada Banana Bread and Cakes Kebumen maka akan semakin meningkatkan kepuasan pelanggan (customer satisfaction). Hasil penelitian ini sejalan dengan penelitian terdahulu yang dilakukan oleh Eva Ristiyani dan Harini Abrilia Setyawati (2019) dengan judul pengaruh service quality, trust terhadap customer satisfactions serta dampaknya pada repatronage intentions pada lazada (studi pada pengguna lazada di kecamatan kebumen) dimana hasil penelitian tersebut yaitu service quality berpengaruh signifikan terhadap customer satisfaction.

\section{Pengaruh marketing mix terhadap customer satisfaction}

Penelitian hipotesis kedua dilakukan untuk mengetahui pengaruh marketing mix terhadap customer satisfaction. Berdasarkan hasil uji t untuk variabel marketing mix diperoleh nilai $t_{\text {hitung }}$ lebih besar dari $t_{\text {tabel }}$ yaitu $3.203>1.985$ dengan nilai signifikansi $0.002<0.05$. Hal ini menunjukan bahwa variabel marketing mix berpengaruh signifikan terhadap variabel customer satisfaction. Hasil ini berarti bahwa semakin banyak strategi bauran pemasaran (marketing mix) yang dilakukan oleh Banana Bread and Cakes Kebumen tentu akan semakin meningkatkan kepuasan pelanggan (customer satisfaction), sebagai contoh produk yang berkualitas dengan harga yang terjangkau merupakan harapan pelanggan, hal ini dapat meningkatkan kepuasan pelanggan (customer satisfaction). Hasil penelitian ini sejalan dengan penelitian terdahulu yang dilakukan oleh Putu Dharmayoga Kusuma dan Alit Suryani (2017) dengan judul peran customer satisfaction memediasi pengaruh marketing mix terhadap repurchase intention dimana menunjukkan hasil bahwa marketing mix memiliki pengaruh yang positif dan signifikan terhadap customer satisfaction. 


\section{Pengaruh customer satisfaction terhadap repurchase intention}

Pengujian hipotesis ketiga dilakukan untuk mengetahui pengaruh customer satisfaction terhadap repurchase intention. Berdasarkan hasil uji $\mathrm{t}$ diperoleh nilai $\mathrm{t}_{\text {hitung }}$ lebih besar dari $\mathrm{t}_{\text {tabel }}$ yaitu $2.655<1.985$ dimana nilai signifikansi $0.009>0.05$. Hal ini menunjukan bahwa variabel customer satisfaction berpengaruh signifikan terhadap repurchase intention. Hasil penelitian ini menjelaskan bahwa terdapat pengaruh yang signifiikan antara tingkat kepuasan konsumen (customer satisfaction), dengan pembelian kembali produk Banana Bread and Cakes Kebumen. Naik turunnya kepuasan konsumen berpengaruh secara signifikan terhadap konsumen yang akan melakukan pembelian kembali. Hasil penelitian ini sejalan dengan penelitian terdahulu yang dilakukan oleh Putu Dharmayoga Kusuma dan Alit Suryani (2017) dengan judul peran customer satisfaction memediasi pengaruh marketing mix terhadap repurchase intention dimana menunjukkan hasil bahwa customer satisfaction memiliki pengaruh yang positif dan signifikan terhadap repurchase intention.

\section{Pengaruh service quality terhadap repurchase intention}

Pengujian hipotesis keempat dilakukan untuk menguji pengaruh service quality terhadap repurchase intention. Berdasarkan hasil uji $\mathrm{t}$ diperoleh nilai $t_{\text {hitung }} 2.312>1.985$ dengan nilai signifikansi $0.023<0.05$. Hal ini menunjukkan bahwa variabel service quality berpengaruh signifikan terhadap variabel repurchase intention. Kualitas layanan (service quality) yang diberikan oleh Banana Bread and Cakes Kebumen memberikan pengaruh kepada konsumen untuk melakukan pembelian ulang (repurchase intention). Semakin baik kualitas layanan (service quality) yang diberikan akan semakin meningkatkan minat pembelian ulang (repurchase intention) pada konsumen produk Banana Bread and Cakes Kebumen. Hasil penelitian ini sejalan dengan penelitian terdahulu yang dilakukan oleh Nuri Mahdi Arsyanti dan Sri Rahayu Tri Astuti (2016) dengan judul analisis pengaruh kualitas produk, kualitas layanan dan keragaman produk terhadap kepuasan pelanggan serta dampaknya terhadap minat beli ulang (studi pada toko online shopastelle, semarang). Hasil dari penelitian ini, menunjukan bahwa service quality berpengaruh secara positif terhadap repurchase intention.

\section{Pengaruh maketing mix terhadap repurchase intention}

Pengujian hipotesis kelima dilakukan untuk menguji pengaruh maketing mix terhadap repurchase intention. Berdasarkan hasil uji $t$ diperoleh nilai $t_{\text {hitung }}$ lebih besar dari $t_{\text {tabel }}$ yaitu $2.737>1.985$ dengan nilai signifikansi $0.007<0.05$. Hal ini menunjukan bahwa variabel marketing mix berpengaruh signifikan terhadap repurchase intention. Hasil tersebut menunjukkan bahwa semakin baik pengelolaan marketing mix, maka konsumen cenderung untuk melakukan pembelian kembali produk Banana Bread and Cakes Kebumen di waktu yang akan datang (repurchase intention). Hasil penelitian ini sejalan dengan penelitian terdahulu yang dilakukan oleh Putu Dharmayoga Kusuma dan Alit Suryani (2017) dengan judul peran customer satisfaction memediasi pengaruh marketing mix terhadap repurchase intention dimana menunjukkan hasil bahwa marketing mix memiliki pengaruh yang positif dan signifikan terhadap repurchase intention.

\section{Pengaruh service quality terhadap repurchase intention melalui customer satisfaction}

Pengujian hipotesis keenam dilakukan untuk menguji pengaruh service quality terhadap repurchase intention melalui customer satisfaction. Berdasarkan hasil uji sobel diperoleh nilai $t_{\text {hitung }}$ lebih besar dari $t_{\text {tabel }}$ yaitu $2.10129036>1.985$ dengan nilai signifikansi $0.03561549<$ 0.05. Hal ini menunjukan bahwa variabel service quality melalui customer satisfaction berpengaruh signifikan terhadap repurchase intention. Hasil tersebut memiliki arti bahwa kualitas pelayanan (service quality) yang dilakukan oleh Banana Bread and Cakes Kebumen 
dapat dimediasi kepuasan pelanggan (customer satisfaction) dalam meningkatkan minat pembelian ulang (repurchase intention). Kepuasan pelanggan (customer satisfaction) dapat menjadi variabel intervening antara service quality dengan repurchase intention. Hasil penelitian ini sejalan dengan penelitian terdahulu yang dilakukan oleh Febry Rosaliana dan Andriani Kusumawati (2018) dengan judul pengaruh sales promotion dan kualitas pelayanan terhadap kepuasan konsumen serta dampaknya pada minat pembelian ulang (survei pada konsumen jasa grabcar di kota malang) Hasil dari penelitian tersebut menunjukan bahwa terdapat pengaruh yang positif dan signifikan antara kualitas pelayanan (service quality) dan minat pembelian ulang (repurchase intention).

\section{Pengaruh marketing mix terhadap repurchase intention melalui customer satisfaction}

Pengujian hipotesis ketujuh dilakukan untuk menguji pengaruh marketing mix terhadap repurchase intention melalui customer satisfaction. Berdasarkan hasil uji sobel diperoleh nilai $t_{\text {hitung }}$ lebih besar dari $t_{\text {tabel }}$ yaitu $2.05655005>1.985$ dengan nilai signifikansi $0.04000957<$ 0.05. Hal ini menunjukan bahwa variabel marketing mix melalui customer satisfaction berpengaruh signifikan terhadap repurchase intention. Hasil tersebut memiliki arti bahwa bauran pemasaran (marketing mix) yang dilakukan oleh Banana Bread and Cakes Kebumen dalam meningkatkan minat pembelian ulang (repurchase intention) dapat dimediasi oleh kepuasan pelanggan (customer satisfaction). Kepuasan pelanggan (customer satisfaction) dapat menjadi variabel intervening antara marketing mix dengan repurchase intention. Hasil penelitian ini sejalan dengan penelitian terdahulu yang dilakukan oleh Putu Dharmayoga Kusuma dan Alit Suryani (2017) dengan judul peran customer satisfaction memediasi pengaruh marketing mix terhadap repurchase intention dimana menunjukkan hasil bahwa customer satisfaction memiliki pengaruh dalam memediasi antara marketing mix terhadap repurchase intention.

\section{Penutup}

\section{Simpulan}

Berdasarkan hasil analisis data yang terkumpul dari kuesioner yang telah disebarkan mengenai service quality dan marketing mix terhadap customer satisfaction dan repurchase intention pada konsumen Banana Bread and Cakes di Kebumen, maka penulis dapat menarik simpulan sebagai berikut:

1. Responden didominasi oleh perempuan dengan jumlah 75 responden atau $75 \%$ dari keseluruhan sampel dengan rentang usia terbanyak yaitu 17-25 tahun dan rata-rata merupakan karyawan swasta yang ada di Kabupaten Kebumen.

2. Berdasarkan hasil data menunjukan bahwa variabel service quality berpengaruh signifikan terhadap customer satisfaction. Hal ini berarti bahwa semakin baik kualitas pelayanan (service quality) pada Banana Bread and Cakes Kebumen maka akan semakin meningkatkan kepuasan pelanggan (customer satisfaction).

3. Berdasarkan hasil data menunjukan bahwa variabel marketing mix berpengaruh signifikan terhadap customer satisfaction. Hal ini berarti bahwa semakin banyak strategi bauran pemasaran (marketing mix) yang dilakukan oleh Banana Bread and Cakes Kebumen tentu akan semakin meningkatkan kepuasan pelanggan (customer satisfaction).

4. Berdasarkan hasil data menunjukkan bahwa variabel customer satisfaction berpengaruh signifikan terhadap repurchase intention. Hal tersebut berarti semakin tinggi kepuasan pelanggan (customer satisfaction) pada konsumen Banana Bread and Cakes maka semakin tinggi minat pembelian ulang (repurchase intention) pada konsumen. 
5. Berdasarkan hasil data menunjukan bahwa variabel service quality berpengaruh signifikan terhadap repurchase intention. Hal ini berarti Semakin baik kualitas layanan (service quality) yang diberikan akan semakin meningkatkan minat pembelian ulang (repurchase intention) pada konsumen produk Banana Bread and Cakes Kebumen.

6. Berdasarkan hasil data menunjukan bahwa variabel marketing mix berpengaruh signifikan terhadap repurchase intention. Hal ini menunjukkan bahwa semakin baik pengelolaan marketing mix, maka konsumen cenderung untuk melakukan pembelian kembali produk Banana Bread and Cakes Kebumen di waktu yang akan datang (repurchase intention).

7. Berdasarkan hasil data menunjukan bahwa variabel service quality melalui customer satisfaction berpengaruh signifikan terhadap repurchase intention. Hasil tersebut memiliki arti bahwa kualitas pelayanan (service quality) yang dilakukan oleh Banana Bread and Cakes Kebumen dapat dimediasi oleh kepuasan pelanggan (customer satisfaction) hanya untuk meningkatkan minat pembelian ulang (repurchase intention). Kepuasan pelanggan (customer satisfaction) dapat menjadi variabel intervening antara service quality dengan repurchase intention.

8. Berdasarkan hasil data menunjukan bahwa variabel marketing mix melalui customer satisfaction berpengaruh signifikan terhadap repurchase intention. Hal ini berarti bahwa bauran pemasaran (marketing mix) yang dilakukan oleh Banana Bread and Cakes Kebumen dalam meningkatkan minat pembelian ulang (repurchase intention) dapat dimediasi oleh kepuasan pelanggan (customer satisfaction).

\section{Keterbatasan}

Dalam penelitian ini, masih terdapat kekurangan dan keterbatasan. Adanya keterbatasan dalam penelitian yang telah dilakukan, diharapkan dapat memberikan evaluasi dan perbaikan untuk penelitian yang akan datang. Keterbatasan dalam penelitian ini antara lain, yaitu:

1. Penelitian ini hanya terbatas pada variabel service quality, makerting mix customer satisfaction serta customer retention.

2. Penelitian ini hanya meneliti satu unit bisnis makanan yang terdapat di Kabupaten Kebumen, sehingga hasil dari penelitian ini tidak dapat digeneralisasikan pada unit bisnis lainnya.

\section{Referensi}

Abdullah, T. (2003). Manajemen Produksi dan Industri Kecil. Jakarta: Pusat Penerbit Universitas Terbuka.

Akhter, N. (2010). Self-management among patient with hypertension in Bangladesh (Doctoral dissertation, Prince of Songkla University).

Anderson, E. W., Fornell, C., \& Lehmann, D. R. (1994). Customer satisfaction, market share, and profitability: Findings from Sweden. Journal of marketing, 58(3), 53-66.

Arsyanti, N. M., \& Astuti, S. R. T. (2016). Analisis Pengaruh Kualitas Produk, Kualitas Layanan dan Keragaman Produk Terhadap Kepuasan Pelanggan Serta Dampaknya Terhadap Minat Beli Ulang (Studi pada Toko Online Shopastelle, Semarang). Diponegoro Journal of Management, 5(2), 291-301.

Ghozali, I. (2018). Aplikasi Analisis Multivariate dengan Program IBM SPSS 25. Semarang: Badan Penerbit Universitas Diponegoro. 
Hawkins, D. I., \& Mothersbaugh, D. L. (2010). Consumer behavior: Building marketing strategy. Boston: McGraw-Hill Irwin,.

Hikmah, A. N., \& Riptiono, S. (2020). Pengaruh Customer Engagement dan E-Service Quality Terhadap Online Repurchase Intention dengan Customer Satisfaction Sebagai Variabel Intervening pada Marketplace Shopee. Jurnal Ilmiah Mahasiswa Manajemen, Bisnis Dan Akuntansi (JIMMBA), 2(1), 89-100.

Hurriyati, R. (2010). Bauran Pemasaran dan Loyalitas Konsumen. Bandung: Alfabetha.

Jimanto, R. B. (2014). Pengaruh Service Quality Terhadap Loyalitas Pelanggan Dengan Customer Satisfaction Sebagai Variabel Intervening Pada Ritel Bioskop The Premiere Surabaya. Jurnal Strategi Pemasaran, 2(1), 1-7.

Kotler, P. (1997). Manajemen Pemasaran. Edisi Bahasa Indonesia jilid satu. Jakarta: Prentice Hall.

Kotler, P., \& Keller, K. L. (2009). Manajemen Pemasaran, Edisi 13. Jakarta: Erlangga, 14.

Kusdyah, I. (2012). Persepsi Harga, Persepsi Merek, Persepsi Nilai, dan Keinginan Pembelian Ulang Jasa Clinic Kesehatan (Studi Kasus Erha Clinic Surabaya). Jurnal Manajemen Pemasaran, 7(1), 25-32.

Kusuma, P. D., \& Suryani, A. (2017). Peran Customer Satisfaction Memediasi Pengaruh Marketing Mix Terhadap Repurchase Intention. E-Jurnal Manajemen Universitas Udayana, 6(3).

Oliver, R. L. (1993). A conceptual model of service quality and service satisfaction: Comparative goals, different concepts. Advances in service marketing and management, 2, 65-85.

Putri, A. D., \& Astuti, S. R. T. (2017). Faktor-Faktor Yang Mempengaruhi Kepuasan Konsumen Serta Dampaknya Terhadap Minat Beli Ulang Konsumen (Studi Pada Blends Pasta \& Chocolate Cabang Unika Semarang). Diponegoro Journal of Management, 6(2), 73-82.

Ristiyani, E., \& Setyawati, H. A. (2019). Pengaruh Service Quality, Trust Terhadap Customer Satisfactions Serta Dampaknya pada Repatronage Intentions pada Lazada (Studi pada Pengguna Lazada di Kecamatan Kebumen). Jurnal Ilmiah Mahasiswa Manajemen, Bisnis dan Akuntansi (JIMMBA), 1(1), 92-100.

Rosaliana, F., \& Kusumawati, A. (2018). Pengaruh Sales Promotion Dan Kualitas Pelayanan Terhadap Kepuasan Konsumen Serta Dampaknya Pada Minat Pembelian Ulang (Survei pada Konsumen Jasa GrabCar di Kota Malang). Jurnal Administrasi Bisnis, 60(1), 139-148.

Sarinah. (2017). Pengantar Manajemen. Yogyakarta: CV Budi Utama.

Sugiyono. (2001). Perilaku Pembelian Konsumen dan Komunikasi Pemasaran. Bandung: Alfabeta.

Tjiptono, F. (2001). Manajemen Pemasaran dan Analisa Perilaku Konsumen, Yogyakarta: BPFE.

Zeng, F., Hu, Z., Chen, R., \& Yang, Z. (2009). Determinants of online service satisfaction and their impacts on behavioural intentions. Total Quality Management, 20(9), 953-969. 